\title{
MANFAAT PENGETAHUAN DASAR TENTANG PERAWAT SEBELUM ANDA MENGAMBIL PROFESI KEPERAWATAN
}

\author{
Alya Tata Riani \\ IIK STRADA INDONESIA \\ alyatata456@gmail.com
}

\begin{abstract}
ABSTRAK
Perawat merupakan tenaga kesehatan yang paling banyak di Indonesia. Tenaga keperawatan yang melakukan tindakan keperawatan harus sesuai dengan kompetensi perawat yang sudah ditetapkan dan didapatkan selama proses pendidikan. Oleh karena itu, tanggung jawab hukum seorang perawat dalam menjalankan praktik mandiri keperawatan harus sesuai dengan standar pelayanan perawat, standar profesi, standar operasional dan kebutuhan kesehatan penerima pelayanan kesehatan. Metode dalam penelitian ini menggunakan pendekatan yuridis normatif, yaitu pendekatan perundang-undangan, pendekatan konseptual dan pendekatan kasus yang pernah terjadi.
\end{abstract}

Kata kunci : Kewajiban, Kode Etik, Perawat, Pelayanan, Tanggung Jawab.

\section{LATAR BELKANG}

Perawat merupakan tenaga kesehatan yang paling banyak di Indonesia. Dalam Kepmenkes RI No. 1239 Tahun 2001 tentang Registrasi dan Praktik Perawat, disebutkan bahwa perawat adalah "Seseorang yang telah lulus pendidikan tinggi keperawatan, baik di dalam maupun di luar negeri yang diakui oleh pemerintah sesuai dengan ketentuan peraturan perundang-undangan". Tenaga keperawatan yang melakukan tindakan keperawatan harus sesuai dengan kompetensi perawat yang sudah ditetapkan dan didapatkan selama proses pendidikan. Oleh karena itu, tanggung jawab hukum seorang perawat dalam menjalankan praktik mandiri keperawatan harus sesuai dengan standar pelayanan perawat, standar profesi, standar operasional dan kebutuhan kesehatan penerima pelayanan kesehatan.

Mengingat kesehatan sebagai hal yang sangat penting maka perlu dilakukan upaya agar pemenuhan kesehatan masingmasing individu dapat terselenggara dengan baik, dimana contohnya yaitu dilakukannya pelayanan kesehatan tanpa adanya diskriminasi dan tidak memberikan pelayanan secara sembarangan/yang tidak 
sesuai dengan prosedur kesehatan. Pihak yang berwenang untuk memberikan pelayanan dalam kesehatan disebut sebagai Tenaga Kesehatan. Penyelenggaraan kesehatan untuk masing-masing individu ini dilakukan oleh tenaga kesehatan, salah satunya adalah perawat. Undang-Undang Nomor 38 tahun 2014 tentang Keperawatan memberikan pengertian mengenai perawat yang menjelaskan bahwa Perawat adalah seorang yang telah selesai dalam menempuh pendidikan tinggi serta lulus pada perguruan tinggi didalam negeri maupun diluar negeri di bidang keperawatan yang standarnya diakui oleh pemerintah sesuai dengan ketentuan yang berlaku.

\section{KASUS / MASALAH}

Kenapa Perawat didalam mengerjakan praktek keperawatan tidak memiliki kewenangan untuk melakukan tindakan medis terhadap pasien ? Bagaimana cara mengetahui kompetensi perawat yang sudah ditetapkan dan didapatkan selama proses Pendidikan?

\section{TINJAUAN PUSTAKA}

Teori Kewenangan Perawat Kewenangan Perawat dalam menjalankan tugas dan profesinya secara prinsip diatur dalam keputusan Mentri Kesehatan Republik Indonesia No.1293/mentri kesehatan/SK/XI/2001, tentang Registrasi dan praktek keperawatan maka dalam menjalankan profesinya maka perawat tidak akan terlepas dari batasan kewenangan yang dimilikinya
Teori Tanggung Jawab Perawat Pertanggung jawaban hukum perawat dapat ditinjau dari hukum itu sendiri berdasarkan Hukum Administrasi maka pertanggung jawaban hukum itu akan bersumber pada masalah kewenangan yang dimilikinya. Pertanggung jawaban hukum perawat bisa dilihat berdasarkan hukum itu sendiri yaitu secara Hukum Admisitrasi, Hukum Perdata dan Hukum Pidana Pertanggung jawaban HukumAdministrasi lahir karena adanya pelanggaran terhadap ketentuan hokum administrasi terhadap penyelenggaraan praktik perawat,

berdasarkan Peraturan Menteri Kesehatan No. 148/2010 ketentuan administrasi yang wajib dilakukan oleh perawat :

a. Surat izin praktik perawat bagi perawat yang melakukan praktik mandiri.

b. Penyelengaraan pelayanan kesehatan berdasarkan kewenangan yang telah

diatur dalam Pasal 8 Undang-undang kesehatan No.36 Tahun 2009

c. Kewajiban untuk bekerja sesuai standar profesi

Tidak adanya persyaratan administrasi akan membuat perawat sangat mudah dikatakan malpraktik. Tidak adanya Surat Ijin Praktik Perawat dalam melakukan pelayanan kesehatan merupakan sebuah administratif malpraktik yang dapat dikenai sanksi hukum, bentuk sanksi administrasi yang ada pada pelanggaran hukum administrasi yaitu ;

a. Teguran lisan, 

b. Teguran tertulis
c. Pencabutan izin

\section{PEMBAHASAN}

Perawat didalam mengerjakan praktek keperawatan tidak memiliki kewenangan untuk melakukan tindakan medis terhadap pasien melainkan hanya memiliki kompetensi untuk melakukan asuhan keperawatan terhadap pasien. Perawat dalam melakukan tindakan medis dikarenakan itu adalah tugasnya sebagai orang yang membantu dokter dan tenaga kesehatan yang lainnya. Perawat diperbolehkan untuk melakukan tindakan apabila sang dokter memberikan pelimpahan kewenangan baik secara lisan dan tertulis ataupun karena keadaan yang tidak mendukung akibat kurangnya dokter dalam suatu daerah sehingga disini perawat bisa melakukan wewenang yang dimiliki seorang dokter terkait dalam pengobatan pasien. Tetapi apabila di daerah tersebut sudah mengalami perkembangan yang cukup maka tindakan perawat yang mengambil alih wewenang dari seorang dokter ini dapat dikategorikan sebagai pelanggaran sehingga dapat diterapkan sanksi atas pelanggaran tersebut.

Kewajiban Perawat dalam menjalankan profesinya harus menjujung tinggi asas professional dan etik yang dimilikinya. Asas etik ini penting dikarenakan sebagai dasar dalam membangun hubungan yang baik dengan seluruh pihak dalam memberikan pelayanan.
Apabila sudah terjalin hubungan baik maka ini menimbulkan kemudahan bagi perawat untuk menjagai tujuannya yaitu pada kesembuhan seorang pasien. Hubungan antara perawat dengan pasien ini sangat dibutuhkan dalam kaitannya pemberian asuhan keperawatan demi tercapainya rasa kekeluargaan. Terkadang muncul juga masalah dalam etik seperti adanya ketidak puasan dari pasien atas pelayanan dari perawat dikarenakan pasien merasa bahwa kebutuhannya tidak dipenuhi oleh perawat dalam melakukan pelayanan. Atas masalah etik ini muncul konflik antara perawat dengan pasien sehingga penyelesaian masalah tersebut hanya bisa diselesaikan dalam ranah hukum. Kode etik yang ada dalam perawat ini adalah sebagai pedoman untuk menghindari munculnya masalah dalam menjalankan tugasnya.

Perawat dalam melakukan praktik keperawatan diharuskan menjunjung asas etik dan profesionalisme. Aspek etik merupakan salah satu pondasi yang sangat penting bagi perawat dalam membangun hubungan baik dengan semua pihak selama melakukan pelayanan keperawatan. Hubungan baik dengan semua pihak yang berperan dalam pelayanan kesehatan dapat mempermudah dalam mencapai tujuan bersama, yaitu kesembuhan dan kepuasan pasien. Interaksi perawat dengan pasien sangat dibutuhkan dalam proses pelayanan keperawatan demi tercapainya kerekatan dan kekeluargaan. Masalah etik keperawatan sebagian besar terjadi pada pelaksanaan pelayanan keperawatan. Rasa ketidakpuasan yang sering kali timbul pada pasien adalah pasien merasa kebutuhannya tidak dipenuhi dan merasa tidak diperhatikan oleh perawat 
dalam pelayanan kesehatan. Masalah etik yang sering muncul menyebabkan konflik antar tenaga kesehatan dengan tenaga kesehatan yang lain maupun dengan pasien, sesuai dengan buku etik . keperawatan dengan penekatan praktik dijelaskan bahwa permasalahan etis yang dihadapi perawat dalam melaksanakan praktik keperawatan telah menimbulkan konflik antara kebutuhan pasien dengan harapan perawat dan falsafah perawat.

Menurut saya kewjiban perawat sendiri adalah berada di samping pasien untuk dapat memantau setiap perkembangan dari pasien. Tetapi terkadang muncul permasalahan, apabila suatu ketika pasien dalam keadaan darurat namun dokter belum memberikan instruksi apa-apa maka saat itulah menyebabkan perawat melakukan tindakan medis yang bukan merupakan kewenangan untuk menyelamatkan nyawa dari pasien tersebut. Tindakan yang dilakukan oleh perawat tersebut tanpa adanya pendelegasian dari pihak dokter dan perawat melakukan tindakan tersebut berdasarkan pengalaman yang dimilikinya.

\section{KESIMPULAN}

1. Pemyataan kode etik perawat dibuat untuk membantu dalam pembuatan standar dan merupakan pedoman dalam pelaksanaan tugas, kewajiban dan hak perawat professional.

2. Perawat dalam menjalankan profesinya harus menjujung tinggi asas professional dan etik yang dimilikinya.

3. Perawat wajib mengetahui hal hal yang dibutuhkan pasien yang kita rawat.

4. Perawat juga manusia, mereka membutuhkan istirahat yang cukup juga untuk bias aktif lagi membantu kesembuhan pasien . 


\section{DAFTAR PUSTAKA}

Sodik, M. A., \& Nzilibili, S. M. M. (2017). The Role Of Health Promotion And Family Support With Attitude Of Couples Childbearing Age In Following Family Planning Program In Health. Journal of Global Research in Public Health, 2(2), 82-89.

Siyoto, S., \& Sodik, M. A. (2015). Dasar metodologi penelitian. Literasi Media Publishing.

Rusmiati, D., \& Hastono, S. P. (2015). Sikap remaja terhadap keperawanan dan perilaku seksual dalam berpacaran. Kesmas: Jurnal Kesehatan Masyarakat Nasional (National Public Health Journal), 10(1), 29-36.

M Soaleh J, M. S. J. (2017). Perlindungan Hak Perempuan Terhadap Tes Keperawanan Menurut HAM dan Hukum Islam (Studi Perbandingan) (Doctoral dissertation, Universitas Islam Negeri Alauddin Makassar).

Attoriq, S., \& Sodik, M. A. (2018). Pencegahan Dan Pengendalian Infeksi Terkait Pelayanan Kesehatan Di Lahan Praktik. 